\title{
"Employee retention and talent management at a sugar mill in South Africa"
}

\begin{tabular}{|c|c|c|}
\hline \multirow{2}{*}{$\begin{array}{l}\text { AUTHORS } \\
\text { ARTICLE INFO }\end{array}$} & \multicolumn{2}{|l|}{$\begin{array}{l}\text { Pierre Joubert } \\
\text { Dolly Madau } \\
\text { Bennie Grobler }\end{array}$} \\
\hline & \multicolumn{2}{|c|}{$\begin{array}{l}\text { Pierre Joubert, Dolly Madau and Bennie Grobler (2017). Employee retention and } \\
\text { talent management at a sugar mill in South Africa. Problems and Perspectives in } \\
\text { Management, 15(3), 306-315. doi:10.21511/ppm.15(3-1).2017.14 }\end{array}$} \\
\hline DOI & \multicolumn{2}{|c|}{ http://dx.doi.org/10.21511/ppm.15(3-1).2017.14 } \\
\hline RELEASED ON & \multicolumn{2}{|l|}{ Wednesday, 08 November 2017} \\
\hline RECEIVED ON & \multicolumn{2}{|l|}{ Friday, 03 March 2017} \\
\hline ACCEPTED ON & \multicolumn{2}{|l|}{ Monday, 28 August 2017} \\
\hline LICENSE & \multicolumn{2}{|c|}{$\begin{array}{l}\text { This work is licensed under a Creative Commons Attribution-NonCommercial } 4.0 \\
\text { International License }\end{array}$} \\
\hline JOURNAL & \multicolumn{2}{|c|}{ "Problems and Perspectives in Management" } \\
\hline ISSN PRINT & \multicolumn{2}{|l|}{$1727-7051$} \\
\hline ISSN ONLINE & \multicolumn{2}{|l|}{$1810-5467$} \\
\hline PUBLISHER & \multicolumn{2}{|c|}{ LLC "Consulting Publishing Company "Business Perspectives" } \\
\hline FOUNDER & \multicolumn{2}{|c|}{ LLC "Consulting Publishing Company "Business Perspectives" } \\
\hline$\sigma^{0}$ & 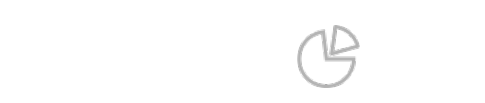 & 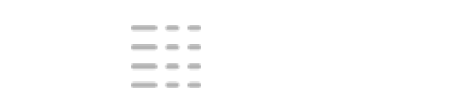 \\
\hline NUMBER OF REFERENCES & NUMBER OF FIGURES & NUMBER OF TABLES \\
\hline 40 & 1 & 1 \\
\hline
\end{tabular}

(c) The author(s) 2023. This publication is an open access article. 


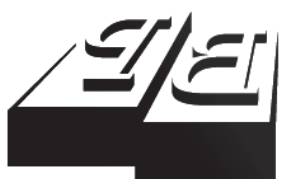

BUSINESS PERSPECTIVES

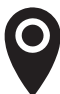

LLC "CPC "Business Perspectives" Hryhorii Skovoroda lane, 10, Sumy, 40022, Ukraine

www.businessperspectives.org

Received on: $3^{\text {rd }}$ of March, 2017 Accepted on: $28^{\text {th }}$ of August, 2017

(c) Pierre Joubert, Dolly Madau, Bennie Grobler, 2017

Pierre Joubert, Ph.D., Head of Department Human Resource Management, Vaal University of Technology, South Africa.

Dolly Madau, MTech: HRM, HR Manager, Sugar Mill, South Africa.

Bennie Grobler, Ph.D., Emeritus Professor, University of Johannesburg, South Africa.

\section{(ㄷ)(1) $(8)$}

This is an Open Access article, distributed under the terms of the Creative Commons Attribution-NonCommercial 4.0 International license, which permits re-use, distribution, and reproduction, provided the materials aren't used for commercial purposes and the original work is properly cited.
Pierre Joubert (South Africa), Dolly Madau (South Africa),

Bennie Grobler (South Africa)

\section{EMPLOYEE RETENTION AND TALENT MANAGEMENT AT A SUGAR MILL IN SOUTH AFRICA}

\begin{abstract}
Talent shortage due to failure by organizations to retain staff with the necessary expertise is becoming a reality and it is important that this challenge is addressed expeditiously. This article focuses on the relationship between employee retention and talent management at a sugar mill with a view to ascertaining whether or not the organization is possibly the reason for employees to leave. The study involved investigating and highlighting the need and importance of talent management, including the attraction and retention of staff with necessary skills. The study touched on the importance of competitive incentives and rewards in the attraction and retention of employees. A survey was conducted among 137 employees. Data were analyzed by means of descriptive and inferential (correlations and regressions) statistics. The interpreted results indicated that staff satisfaction leads to high productivity and plays a significant role in the retention of staff. The results further indicated that management strategies are not being used to the extent that they should be in the retention of talent, whilst most respondents felt that fringe benefits that used to be offered by the organization had a positive influence on staff satisfaction and on the retention of talented employees. The study revealed a commonly held perception by the non-designated group that people from designated groups use the provisions of the Employment Equity Act to find better opportunities with other organizations.
\end{abstract}

\section{Keywords}

employee retention, talent management, sugar mill, South Africa

\section{JEL Classification J23, J24, J28, M52, M54, Z13}

\section{INTRODUCTION}

Talent management (TM) involves putting employees before strategy and ensuring that they are valued as greatest assets. Ehlers and Lazenby (2007) confirm that the greatest mistake managers make is to forget about the most important factor when it comes to management, namely the human being. They are not shown on the balance sheet, but are the most important aspect when it comes to successfully implementing the organization's strategies. TM is also about an organization having a sense of urgency about their people who are in leadership and critical positions (Conaty \& Charan, 2010). Maritz (2012) predicts that the demand for talent in Africa will outstrip supply and, as a result of the higher demand for talent, the price of it is and will continue to rise for as long as there is a skills shortage. Maritz (2012), however, emphasized the importance of organizations growing local talent, as opposed to rushing to appoint expatriates to run local businesses.

Employee retention and talent management are contentious topics in all fields, as a result of but not limited to the shortage of skilled labor, economic growth and employee turnover (Herman, 2010). For 
Maxwell (2007), another factor is the intense competition among companies to employ qualified professionals and university graduates from the small number of such persons available. The competition for talented employees, according to Armstrong (2002), is fuelled by three fundamental forces, namely, an irreversible shift from the industrial age to the information age, intensifying demand for high-calibre management talent and a growing propensity for people to switch from one company to another. Since these structural forces show no signs of abating, the struggle for talented management will be a defining feature of the business landscape for many years to come. In the South African context, there is the added complication of having to employ certain quotas from the various ethnic groups in order to meet the requirements of the Employment Equity Act (55 of 1998). Competent people must be available to nurture and sustain the business over a long time, hence it is necessary for organizations to review their policies and procedures relating to the attraction and retention of employees to ensure they remain with the company (Schultz, Bagraim, Potgieter, Viedge, \& Werner, 2003).

\section{LITERATURE REVIEW}

In order to evaluate the magnitude of the staff attraction and retention challenge faced by organizations, a review of literature was conducted on the elements discussed below.

\subsection{The fringe benefits and rewards of staff attraction}

The degree to which employees are motivated is influenced to a certain degree by their rewards (Hassink \& Koning, 2005). Strack, Dyer, Caye, Minto, Francoeur, Ang, Bohm, McDonnell, and Leicht (2008) revealed that in order for organizations to reward good performance with financial compensation, they must be able to measure the performance and ensure a balance between pay and performance. Some organizations are now competing in order to differ from others by customizing their total rewards packages to best meet individual needs of employees. This is so, since people want to feel that they are being taken care of and appreciated as individuals, not as groups. Simply offering a more flexible package can make or break a decision to stay or leave to join the competitor (Fitz-Enz, 2010).

According to Robbins and Odendaal (2003), rewards and satisfaction are linked and have an effect on staff retention, as well as playing a role in decreasing labor turnover. Nieman and Bennett (2007) stated that the consequence of dissatisfaction with the remuneration package can result in poor performance, job dissatisfaction and grievances, all of which can lead to increased labor turnover. If employees perceive the relation- ship between their pay and their performance to be incoherent, the result will be low performance and a decrease in job satisfaction. This will then translate to an increase in turnover and absenteeism (Robbins et al., 2003). This thinking was confirmed by Hellriegel et al. (2001), whose opinion was that low salaries often led to absenteeism and turnover.

\subsection{The none-effectiveness of the exit interview process}

The final retention strategy is that of the exit interview with the departing employees. It is conducted at the time an employee resigns from an organization and is intended to ascertain the reasons why the employee has decided to leave. The information given may then be used to change or improve strategies to retain remaining staff. In an impartial environment, the chances are good that the departing employee will be forthcoming and honest about his or her reasons for leaving (Dippenaar, 2010).

\subsection{Management retention strategies}

An organization cannot become a talent master without the wholehearted commitment and full participation of an enlightened leadership team, including the chief executive officer. This refers to leadership that understands the importance and benefits of building talent and regards that as priority, so that the same talent will be the organization's legacy (Conaty et al., 2010). Brevis (2007) stated three important aspects of effective leadership, namely, influence, shared purpose and 
change, all of which are powerful interventions that leadership can put to good use in the retention of staff. It is therefore important for leadership not only to drive the effort but also to instil values and behaviors that make people development and talent management an integral part of running the business.

\subsection{The effects of staff satisfaction on the retention of staff}

Employees in general will display signs of satisfaction when they know that their efforts and hard work will somehow lead to performance appraisal or a reward, such as a substantial salary increase, a bonus, a promotion or performance-related exgratia payment. Such rewards are seen by employees as a means to the attainment of their expectations and results in employee satisfaction. Unmet expectations, according to Nel, Gerber, van Dyk, Haasbroek, Schultz, Sono, and Werner (2002), contribute to staff dissatisfaction, absenteeism for no reason and the abuse of sick leave. Satisfied, committed and motivated employees tend to have lower rates of turnover and absenteeism, which can be a benefit to an organization (Robbins, Odendaal, \& Roodt, 2003). Gibson, Ivancevich, and Donnelly (2000) concluded that absenteeism and turnover, no matter the cause, is a costly and disruptive problem facing managers in businesses. Teoh, Tan, Chong, and Wooi (2012) highlighted the importance of determining job satisfaction levels amongst employees, as this is an important element that can affect the total operation or production of an organization. They identified four predictors of job satisfaction as illustrated below:

Job satisfaction levels are also determined by other variables, such as age group, number of years' service, education level and job level. This requires employers to formulate appropriate long-term plans to avoid high turnover and/or job burnout amongst their employees (Teo et al., 2012).

\subsection{Motivation strategies}

People work not only for obvious reasons, such as earning a salary, but also because it plays an important role in the development of self-respect and gives them a sense of identity. Some of the most important needs include affiliation, a feeling of competence and success, authority, control, pride and status. It is important for management in organizations to be aware of human needs and existing theories of motivation so as to motivate their workforce effectively (Brevis, 2007). Thomas

Source: adapted from Teoh, Tan, Chong, and Wooi (2012, p. 595).

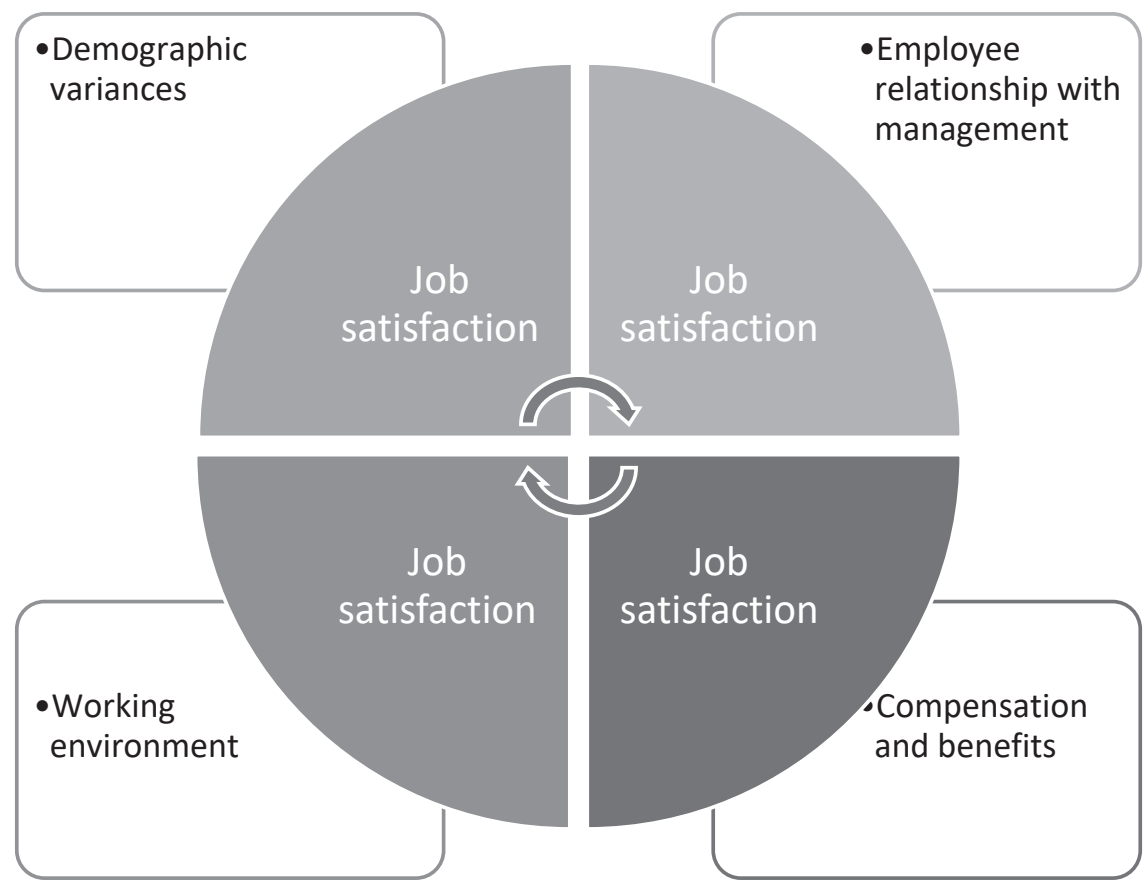

Figure 1. The four predictors of independent variables to job satisfaction 
(2009) stated that motivational dynamics have changed dramatically in recent years to reflect new work requirements and changed worker expectations. One of the largest changes he highlights is the rise in importance of psychic or intrinsic rewards, and the decline of material or extrinsic rewards. Motivated employees are more likely to go to work and their levels of morale remain high if they feel wanted and respected in the organization. People have a perception that if they work hard this will lead to more value in terms of rewards and fewer negative consequences (Gibson et al., 2000). Brevis (2007) confirmed that people with a high need for achievement want and accept a high degree of personal responsibility. They set realistic performance goals, take calculated risks and show a need for concrete feedback on their actions. The goal, according to Buys (2010), has to be both motivational and realistic in order for the employee to achieve it.

\subsection{Employee commitment and turnover}

Employee commitment is key and a driving force from all levels of the organization's hierarchy (Schultz et al., 2003). According to Greenberg and Baron (2006), low levels of organizational commitment can result in low employee commitment and become associated with high levels of absenteeism and voluntary labor turnover. This is because employees with low commitment levels tend to have a negative attitude towards work. Strack et al. (2008) confirmed the argument that highly committed and engaged employees bring value to an organization. The authors claimed that in enhancing employee commitment, human resources must deliver tools, systems and processes, but assert that the most important issue is for line managers to work with the people. There is, however, conventional wisdom that pronounces that dissatisfied employees will leave an organization and that they will show commitment to it if they are well looked after and adequately remunerated (Mitchell, Holtom, \& Lee, 2001).

\subsection{Attitudes of employees}

According to Schultz et al. (2003), attitudes can be described as a predisposition or tendency to respond positively or negatively towards a certain idea, object, person or a situation. They are influenced by values and can influence an individual's choice of action and responses to challenges, incentives or rewards. The responses can either make or break an organization if not properly managed. Negative attitudes give warnings of a potential problem for an organization, hence, it is important for managers to attend to them. Attitudes of employees, whether good or bad, have an effect on an organization. Many organizations periodically measure the attitudes of employees towards their jobs, teams and supervisors by means of questionnaires. Based on the results, managers, in collaboration with employees, draw up a plan to improve the situation (Schultz et al., 2003). Disengaged employees and employees with negative attitudes are not interested in their work, are careless, and at times drop equipment, waste materials and often refuse to accept responsibility for their work. An organization with such negative employees will be vulnerable; therefore, it is important for leadership to create a climate that enables employees to unleash their full potential.

\subsection{Biographical characteristics influencing staff attraction and retention}

The biographical characteristics that influence staff attraction and retention are discussed in detail below.

\subsubsection{Age}

The average age of the workforce has an influence on staff retention, as, in general, older employees are bound to stay longer in an organization and not be as quick to look for better opportunities as the younger age band. Older employees are not easy to relocate due to family commitments and fear of the unknown, whilst the younger generation have fewer family commitments and more easily adapt to a new environment. In general, older employees have lower rates of avoidable absence than young employees. On the other hand, older employees have higher rates of unavoidable absence due to but not limited to poor health conditions associated with age and longer periods of recovery when injured (Robbins et al., 2003).

Armstrong (1999) confirms that younger employees are more frequently absent at work 
than older colleagues. This may be exacerbated by but not limited to the number of interviews they attend in other organizations. This analysis is evident from the research analysis of the time and attendance reports at the sugar mill, which revealed that younger employees are more frequently absent than older ones for many different reasons. Thomas (2009) highlighted that younger workers come to organizations with different expectations than their parents. Raised during an era of rapid technological change and instant access to data, they respond best to work that is more meaningful and work that allows them to learn cutting-edge skills and allows them to find their own ways of accomplishing tasks.

\subsubsection{Gender}

Robbins and Odendaal (2003) confirm that women have higher rates of absenteeism than men, but lower turnover rates. This is often due to the cultural responsibilities placed on women to stay at home to attend to domestic and family matters. When a child or other member of the family is ill and needs care, it has traditionally been the woman who has taken time off from work. Ichino and Moretti (2009) added that the menstrual cycle of women increased female absenteeism from work. This claim is supported by Wilson (2009) in that home-related duties placed on females in most instances forced them to stay with the same organization for extended times.

\subsection{The influence of the Employment Equity Act (EEA) 55, of 1998 on talent retention}

That South Africa is a very diverse society needs to be understood, appreciated, valued, utilized, celebrated, respected and well managed in order to minimize disadvantages, whilst also maximizing advantages for individuals, organizations and broader society (Bongwe, 2010). The demography of the South African workforce has changed considerably since the implementation of the EEA. The rationale for introducing the EEA was to enforce transformation on the basis that organizations would not empower sufficient numbers of Black employees of their own free will.

\section{METHODOLOGY}

\subsection{Research sample}

The target population comprised employees from the sugar mill, both male and female between the ages of 19 and 63 . For this study, the sample size was 137 employees, which was $50.7 \%$ of the actual complement of 270 .

\subsection{Method of data collection}

The primary data were collected by means of a structured questionnaire that was distributed to all employees using online tools. They were asked to complete it anonymously, to ensure that responses received were truthful and completed honestly.

\subsection{Measuring instrument}

Nominal scales were used to categorize the variables in Section A of the questionnaire. Respondents were grouped according to race, gender, age, educational qualifications, job grade and years' service with the company. Sections B and $\mathrm{C}$ were used to gather information on motivation, staff benefits, staff morale, staff attraction and retention, and how some of the provisions of the EEA had an effect on talent management. The responses from Sections B and C were scored on a six-point scale, ranging from 1 , strongly disagree to 6 , strongly agree. The questionnaire had a covering letter with instructions on how to complete it and reasons it was being conducted. It also assured the respondents of the confidential nature of the research and stated that they were free to remain anonymous if they so wished.

\subsection{Statistical analysis}

The Statistical Package for Social Sciences (SPSS 21.0 for Windows) was used to process the raw data from the questionnaire (Norusis, 2009). Descriptive statistics were initially compiled to analyze the composition of the sample and so determine its representativeness. Correlation coefficients were used to measure the relationship between talent management and staff retention, and regression analyses to determine the percentage variance in the dependent variable predicted by the independent variable (Maree, 2010). 


\section{RESULTS AND DISCUSSIONS}

\subsection{Descriptive analysis}

The overall majority of respondents were Black males on Patterson grades A and B who had less than ten years work experience at the mill. All age categories were equally represented and all respondents had at least a grade 12 certificate.

\subsection{Factor analysis results}

The investigation of a possible relationship between talent management and staff retention via the perspective of the present employees involved constructs which are latent or hidden. Talent management and employee retention consist of numerous facets, which in turn consist of numerous variables. In order to identify which variables are involved in the various constructs, Principal Axis Factoring (PAF) was performed to reduce the numerous variables involved to a more parsimonious number of factors, while retaining as much of the information as possible (Field, 2009). The following five first-order factors were identified:

- FB 1.1 - Management strategies.

- FB 1.2 - Staff satisfaction.

- FB 1.3 - Employee benefits.

- FB 1.4 - Influence of the EEA.

- FB 1.5 - Staff motivation.

Principal Axis Factoring (PAF) with varimax rotation was used as the KMO value of 0.514 , and Bartlett's sphericity of $p=0.0000$ indicated that it would be feasible. Although the KMO value is regarded as mediocre, the Bartlett's test was significant, indicating that the correlations between variables were (overall) significantly different from zero (Field, 2009). The Monte Carlo parallel analysis indicated that five factors should be retained. Five factors thus resulted, which explained $40.2 \%$ of the variance present.

When the five first-order factors were subjected to a further factor analytic procedure with varimax rotation, only one factor resulted. It was named talent management and staff retention (FB2.0). A multiple regression analysis was conducted to determine which of the five first-order factors could be classified as being the best predictors of the talent management and staff retention factor. The following relevant values were determined: $R^{2}=0.89 ; \Delta F(1.132)=148.32 ; \quad p<0.0005$; Durbin-Watson $=2.86$.

The standardized coefficient $(\beta)$ of each of the factors involved is given in Table 1 below.

The data in Table 1 indicated that the management strategies and talent retention factor (FB1.1) was the most important predictor, with a Beta value of $\beta=+.550$. Thus, as the management strategies and talent retention (FB1.1) increased by one standard deviation, the talent management and staff retention factor (FB2.0) increased by 0.550 standard deviations units (Field, 2009). This was followed by work satisfaction and talent retention $(\beta=+.419)$ and the influence of the EEA on talent retention $(\beta=0.414)$. The motivation

Table 1. The coefficients of the regression model

\begin{tabular}{|c|c|c|c|c|c|c|}
\hline & \multirow{2}{*}{$\underset{\text { B }}{\text { Model }}$} & \multicolumn{2}{|c|}{ Unstandardized coefficients } & \multirow[t]{2}{*}{$\begin{array}{c}\text { Standardised } \\
\text { coefficients }\end{array}$} & \multirow[t]{2}{*}{$\mathbf{T}$} & \multirow[t]{2}{*}{ Sig. } \\
\hline & & Std. Error & Beta & & & \\
\hline \multirow{5}{*}{4} & (Constant) & 1.034 & .097 & - & 10.636 & .000 \\
\hline & $\begin{array}{l}\text { FB1.1 - theoretical factor on } \\
\text { management strategies and } \\
\text { talent retention }\end{array}$ & .262 & .014 & .550 & 18.641 & .000 \\
\hline & $\begin{array}{l}\text { FB1.2 - theoretical factor on } \\
\text { work satisfaction and talent } \\
\text { retention }\end{array}$ & .210 & .015 & .419 & 14.233 & .000 \\
\hline & $\begin{array}{l}\text { FB1.4 - theoretical factor on } \\
\text { the influence of the EEA on } \\
\text { talent retention }\end{array}$ & .172 & .012 & .414 & 13.956 & .000 \\
\hline & $\begin{array}{l}\text { FB1.5 - theoretical factor } \\
\text { on motivation and staff } \\
\text { retention }\end{array}$ & .149 & .012 & .360 & 12.179 & .000 \\
\hline
\end{tabular}


and staff retention factor was seen as the fourth most important predictor with a $\beta=+.36$. Surprisingly, FB1.3, the company benefits factor was not a significant predictor in this model.

\subsubsection{Comparing two independent groups for significant differences on the five first- order factors}

When testing for significant differences between the factor means of two independent groups, Levene's $t$-test was used to determine whether the variances are different between the two groups involved. If the variances are similar $(p>0.05)$, then equal variances are assumed and if they are significantly different $(p<0.05)$, then equal variances are not assumed. With respect to nonparametric statistics, the Mann-Whitney $U$-test can be utilized. No statistically significant differences could be found between males and females on any of the two independent groups, namely gender and job category recoded to two groups. There were only 17 female respondents, and this was probably too few to record any significant differences.

\subsubsection{Comparison between three or more independent groups for significant differences between the mean scores}

\section{Age as independent variable}

The only difference that could be found for age groups was with respect to the factor motivation and staff retention (FB1.5). When the three groups were compared, the ANOVA test gave the following results:

$$
\begin{aligned}
& \bar{X}_{<34}=3.21 ; \bar{X}_{35-43}=3.64 ; \\
& \bar{X}_{44-51}=3.53 ; \bar{X}_{52+}=3.57 ; \\
& F(3.133)=3.74 ; p=0.013 ; r=0.28 .
\end{aligned}
$$

The lowest age group (less than 34 years old) had the lowest mean score, while the age group (35 to 43 years old) had the highest mean score with respect to motivation and staff retention. Although both age groups partially disagreed with the factor, the lowest age group disagreed more strongly, as indicated by a pair-wise comparison using the Dunnett T3 test $(p<0.05)$.

\section{Highest educational qualification}

The educational qualifications groups were recoded to four groups. There were statistically significant differences regarding factor FB1.2 (staff satisfaction and talent retention) and FB1.4 (influence of the EEA and staff retention). With respect to staff satisfaction, the result of the comparison of the four qualification groups was:

$$
\begin{aligned}
& \bar{X}_{M}=4.25 ; \bar{X}_{C}=4.56 ; \\
& \bar{X}_{D}=4.52 ; \bar{X}_{D / P G}=4.72 ; \\
& F(3.133)=4.95 ; p=0.005 ; r=0.32 .
\end{aligned}
$$

The respondents with only a matriculation certificate had the lowest factor mean and differed statistically significantly from respondents with a degree or postgraduate qualification at the $1 \%$ level $(p<0.01)$. Respondents with a matriculation certificate partially agreed with the factor, while graduate and postgraduate respondents tended to agree with the factor regarding staff satisfaction and talent retention. Persons with higher educational qualifications probably have more opportunities for promotion and most probably belong to at least middle management levels. As such, it is more likely that they will have more positive perceptions regarding staff satisfaction and talent retention (32 respondents $(23.4 \%)$ had a degree or a higher qualification).

The comparison of the influence of the EEA on talent retention revealed the following data:

$\bar{X}_{M}=4,50 ; \bar{X}_{C}=4.23$;

$\bar{X}_{D}=4.35 ; \bar{X}_{D / P G}=4.93$;

$F(3.133)=9.92 ; p=0.000 ; r=0.43$.

Thus, while all four qualification groups partially agreed with this factor, the respondents with degrees and postgraduate qualifications agreed to a statistically significantly larger extent. Respondents with matriculation certificates differed from the highest qualification groups at the $5 \%$ level $(p<0.05)$, while the certificate and diploma groups differed from the highest qualification group at the $1 \%$ level $(p<0.01)$. The effect size could be classified as moderate and, hence, the practical significance could be that the well- 
qualified persons had a perception that they were more vulnerable to the EEA. This could also be related to racial classification, as 17 (94.4\%) of respondents with a degree or higher qualification indicated that they belonged to the White racial category and, as such, they were more vulnerable to the requirements of the EEA.

\section{Race category}

The only factor in which statistically significant differences were found was that related to the influence of the EEA on talent retention. The ANOVA test results were:

$$
\begin{aligned}
& \bar{X}_{B}=4.37 ; \bar{X}_{C}=4.25 ; \\
& \bar{X}_{I}=4.65 ; \bar{X}_{W}=4.99 ; \\
& F(3.129)=6.903 ; p=0.000 ; r=0.37 .
\end{aligned}
$$

Thus, although all racial categories at least partially agreed with the items in this factor, respondents who indicated that they belonged to the Black and Colored race categories had the lowest factor means, while the respondents who indicated that they belonged to the White race category tended to agree with the factor, as did the Indian category. The Black and Colored respondents differed from the White respondents at the $1 \%$ level of statistical significance.

\subsection{Empirical findings}

All five factors had Cronbach reliability coefficients high enough $(>0.70)$ to allow inferential statistical tests to be conducted. Respondents disagreed with the items in the factor "management strategies and talent retention $\left(\bar{X}_{F B 1.1}=2.69\right)$ indicating that the management strategies contained in the items were not being sufficiently utilized. The respondents partially agreed $\left(\bar{X}_{F B 1.2}=4.52\right)$ with the items in the factor concerned with staff satisfaction and talent retention. However, the respondents disagreed that exit interviews assisted in retaining staff, as well as disagreed that the present fringe benefits were conducive to talent retention. With respect to the third factor (FB1.3), respondents agreed that the company benefits that used to be of- fered to employees acted as an aid to retaining talented staff $\left(\left(\bar{X}_{F B 1.3}=5.0\right)\right.$. Regarding the influence of the EEA on talent retention, the respondents partially agreed with the items in the factor $\left(\bar{X}_{F B 1.4}=4.48\right)$. Respondents partially disagreed $\left(\bar{X}_{F B 1.5}=3.48\right)$ with the items in the factor motivation and staff retention.

A multiple regression procedure indicated that the most important factor in predicting talent management and staff retention was management strategies and talent retention (FB1.1), followed by work satisfaction and talent retention (FB1.2) and the influence of the EEA on talent retention having virtually the same Beta values. The fourth most important predictor was motivation and talent retention (FB1.5).

A statistically significant association was found to be present between the age groups and motivation and staff retention in the sense that the older the respondents were, the more they agreed with the motivation and retention factor.

The highest educational qualification categories also indicated statistically significant associations with FB1.2 (staff satisfaction and talent retention), where the respondents with the lower educational qualification had a lower factor mean than the higher qualification group had. The association is thus a direct one in the sense that the lower the educational qualifications were, the lower was the agreement with staff satisfaction and talent retention. There was also a statistically significant relationship present between the qualification groups and the perceived influence of the EEA on talent retention (FB1.4). The higher the qualification group, the greater the extent of agreement with the influence of the EEA on employee retention.

Most of the items in this factor focused on the dysfunctional or unintended influences of the EEA and the better qualified individuals were probably more aware of these unintended consequences than those with lower educational qualifications. The racial groups also differed statistically significantly with respect to their factor mean scores, as obtained on the influence of the EEA on talent retention (FB1.4). 


\section{CONCLUSION}

There are a number of factors that have an effect on staff attraction and retention, ranging from, inter alia, employee benefits, motivation, management strategies, the EEA, staff satisfaction, employee morale, attitudes and rewards. All the factors require careful management, if an organization hopes to attract and retain the calibre of employees required to take it to the future. Therefore, the following recommendations are made:

- It is recommended that the organization measures employee satisfaction on an annual basis and so ensures current practices and rewards are still appreciated by employees, thereby assisting in the retention of staff.

- The organization should reconsider the issue of benefits, especially accommodation and transport to and from work, to ensure the retention of employees.

- The organization should identify all issues causing dissatisfaction earlier and attempt to resolve them before employees see that such a gap exists.

- It is important for the organization to appreciate individual differences in people and utilize those differences to ensure they give the organization a competitive edge and increase job satisfaction.

- The current pay structure needs to be looked into and compared against other organizations in the industry and aligned to market pay rates.

- The organization will have to enforce a performance management system that insists targets are aligned with individual behavior and enterprise goals, as well as providing feedback and follow-ups that are visible to all employees.

- The organization should foster a culture of recognition and appreciation for superior performance in order to enhance employee commitment.

- The current system of rewarding all employees by way of a performance related bonus based on group performance is not effective, as it also rewards poor performers and should be replaced by a system rewarding individual performance.

- The organization should ensure fair treatment of all employees to avoid employee dissatisfaction. Employees are not always motivated by receiving an increased salary; a simple "thank you" goes a long way to motivate a person to make an extra effort and improve productivity. This should be encouraged and practiced by all managers.

- It is important for the organization to employ and retain talent, and, most importantly, those from designated groups for equity purposes or risk the plight of paying heavy fines for non-conformance.

\section{REFERENCES}

1. Armstrong, M. (1999). A Handbook of human resources management practice. ( $\left.7^{\text {th }} \mathrm{ed}\right)$. London: Kogan Page.

2. Armstrong, M. (2002). Employee rewards ( $\left.3^{\text {rd }} \mathrm{ed}\right)$. London: Cromwell Press.
3. Berger, L. A., \& Berger, D. R. (2004). The talent management handbook. McGraw Hill: CWL Publishing Enterprises.

4. Bongwe, S. I. (2010). 100 Lessons in diversity. Johannesburg: Fishwicks Printers.
5. Brevis, T. (2007). Basics of management. Pretoria: Pro Copy Print.

6. Brevis, T., Ngambi, H. C., Vrba, M. J., \& Naicker, K. S. (2004). Management principles: $a$ 
contemporary edition for Africa ( $3^{\text {rd }}$ ed). Cape Town: Oxford University Press.

7. Conaty, B., \& Charan, R. (2010). The talent masters: why smart leaders put people before numbers. New York: Random House.

8. Covey, S. R. (2005). The $8^{\text {th }}$ habit: from effectiveness to greatness. New York: Free Press.

9. Deery, M. (2008). Talent management work-life balance and retention strategies. Retrieved from http://www.emeraldinsight. $\mathrm{com} /$ case_studies.htm/case_studies. htm?articleid $=174787$ (accessed on January 17, 2014).

10. Dippenaar, M. (2010). Talent retention. Are employees fixed assets or free agents. Retrieved from http://www.skillsportal.co.za/page/ human-resources/recruitmentselection/597303-Are_employees_fixed_assets_or_free_agents (accessed on January 31, 2014).

11. Ehlers, T., Lazenby, K. (2007). Strategic management $\left(2^{\text {nd }}\right.$ ed). Pretoria: CTP Book Printers.

12. Field, A. (2009). Discovering statistics using SPSS ( $3^{\text {rd }}$ ed). London: Sage.

13. Fitz-enz, J. (2010). The new HR analytics: predicting the economic value of your company's human capital investments. New York: Amacom Books.

14. Gibson, J. L., Ivancevich, J. M., \& Donnelly, J. J. (JR.) (2000). Organizations: behaviour, structure, processes $\left(10^{\text {th }} \mathrm{ed}\right)$. New York: McGraw-Hill.

15. Greenberg, G., \& Baron, R. A. (2000). Behaviour in organizations ( $6^{\text {th }}$ ed). New Jersey: Prentice-Hall.

16. Hassink, W., \& Koning, P. (2005). Do financial bonuses to employees reduce their absenteeism? Outcome of a lottery. Journal of economics and business, 37(2), 1-37.

17. Hellriegel, D., Jackson, S. E., Slocum, J., Staude, G., Amos, T., Klopper, H. B., Louw, L., \& Oosthuizen, T. (2001). Management: South African edition. Cape Town: Oxford University Press.

18. Herman, R. E. (2010). Retention connection. Retrieved from http:// www.retentionconnection.com (accessed on May 14, 2010).
19. Ichino, A., \& Moretti, E. (2009). Biological gender differences, absenteeism and the earnings Gap. American economic journal: applied economics, 1(1), 183-217.

20. Lumley, E. J. (2009). Exploring the relationship between career anchors, job satisfaction and organizational commitment. (M Tech dissertation). University of South Africa: Pretoria.

21. Luthans, F. (2002). Organizational Behaviour ( $9^{\text {th }}$ ed). New York: McGraw-Hill.

22. Maree, K. (2010). First steps in research $\left(6^{\text {th }} \mathrm{ed}\right)$. Pretoria: Van Schaik.

23. Maritz, J. (2012). Talent grab: how top companies are managing Africa's skills shortage. Retrieved from http://www.howwemadeitinafrica.com/talent-grab-how-toopcompanies-are-managing (accessed on January 14, 2014)

24. Maxwell, J. C. (2007). Talent is never enough. California: Thomas Nelson Inc.

25. Mitchell, T. R., Holtom, B. C., \& Lee, T. W. (2001). How to keep abreast employees: developing an effective retention policy. The academy of management executive journal, 15(4), 96-108. Retrieved from http:// amp.aom.org/content/15/4/96.short (accessed on February 11, 2014).

26. Nel, P. S., Gerber, P. D., Van Dyk, P. S., Haasbroek, G. D., Schultz, H. B., Sono, T., \& Werner, A. (2002). Human resources management (5th ed). Cape Town: Oxford University Press.

27. Nieman, G., \& Bennett, A. (2007). Business management: a value chain approach ( $2^{\text {nd }}$ ed). Pretoria: Van Schaik.

28. Norusis, M. J. (2009). PASW Statistics 18. Statistical procedures companion. Upper Saddle River: Prentice Hall

29. Oosthuizen, R. M., Naidoo, V. (2010). Attitudes towards and experience of employment equity. SA journal of industrial psychology. Retrieved from http://sajip.co.za/index.php/sajip/article/view/836/960 (accessed on February 11, 2014).

30. Rao, H., Drazin, R. (2002). Overcoming constraints on product innovation by recruiting talent from rivals. Academy of management journal, 3(45), 491-507.

31. Ray, L. (2014). Everyday Life global post. The effects of employee attitudes on productivity in the workplace journal. Retrieved from http://everydaylife.globalpost. com/effect-employee-attitudesproductivity-workplace-3168.html (accessed on February 10, 2014).

32. Republic of South Africa (1998). The Employment Equity Act, No. 55 of 1998. Pretoria: Government Printer.

33. Robbins, S. P., Odendaal, G., \& Roodt, G. (2003). Organizational behaviour. Global and Southern African perspectives. Cape Town: Pearson Education.

34. Schultz, H., Bagraim J., Potgieter, T., Viedge, C., \& Werner, A. (2003). Organizational behaviour. Pretoria: Van Schaik.

35. Strack, R., Dyer, A., Caye, J., Minto A., Francoeur, F., Ang, D., Bohm, H., McDonnell, \& Leicht, M. (2008). Creating people advantage: how to address HR challenges worldwide through 2015. Boston Consulting Group.

36. Teoh, W. M., Tan, K., Chong, S., \& Wooi, L. (2012). Job satisfaction level among human resource employees: Malaysia's perspective. African journal of business management. Retrieved from http:// www.academicjournals.org/journal/ AJBM/article-abstract/fe $72 \mathrm{fb} 218203$ (accessed on January 24, 2014)

37. Thomas, K. (2009). The four intrinsic rewards that drive employee engagement. Retrieved from http://www.iveybusinessjournal.com/topics/the-workplace/thefour-intrinsic-rewards-that-driveemployee-engagement (accessed on January 24, 2014).

38. Tosi, H. L., Risso, J. R., \& Carroll, S. J. (1995). Managing organizational behaviour ( $3^{\text {rd }}$ ed). Oxford: Blackwell Business.

39. Wilson, D. C. (2009). Note on the effects of home duties on factory employment of women. Journal of hygiene, 45(4), 43-433.

40. Zikmund, W. G. (2000). Business research methods ( $6^{\text {th }}$ ed). Fort Worth, Texas: Dryden. 